Check for updates

Cite this: RSC Adv., 2017, 7, 33327

\title{
Inhibition of the reaction between aluminium dust and water based on the $\mathrm{HIM}^{\dagger}$
}

\author{
Yantong Wang, Kaili Xu D * and Li Li \\ Aluminium dust can react with water to produce hydrogen. The existence of hydrogen can bring about the \\ risk of fire or explosive accidents in wet dust removal systems. A hydrogen fire or an explosion accident can \\ lead to property damage and casualties in factories. Through a hydrogen inhibition experiment using \\ $\mathrm{CrK}\left(\mathrm{SO}_{4}\right)_{2} \cdot 12 \mathrm{H}_{2} \mathrm{O}$ solution, the Hydrogen Inhibition Method (HIM) was proposed. The aluminium \\ particles before and after the reaction were characterized by Scanning Electron Microscopy (SEM), X-ray \\ diffraction (XRD), X-ray Photoelectron Spectroscopy (XPS) and Energy Dispersive Spectroscopy (EDS). \\ $\mathrm{Al}(\mathrm{OH})_{3}$ and $\mathrm{Cr}(\mathrm{OH})_{3}$ were generated and covered the surface of the aluminium particles, thus \\ preventing contact between the aluminium core and water. Based on the shrinking core model, the \\ physicochemical mechanism of the reaction was clarified. The HIM is low cost and can effectively inhibit \\ hydrogen production. The HIM can be used in wet dust removal systems for the treatment of aluminium \\ dust to reduce the risk of hydrogen fire or explosion-accidents.
}

Received 28th April 2017

Accepted 26th June 2017

DOI: $10.1039 / \mathrm{c} 7 \mathrm{ra0} 4787 \mathrm{~h}$

rsc.li/rsc-advances

compensation, factory equipment maintenance and other associated costs will be quite high.

The technology of hydrogen production by the reaction Aluminium is the most abundant metal on earth and constitutes approximately $8.2 \%$ of the earth's crust. ${ }^{1,2}$ When aluminium is present in particulate form, aluminium particles can react with water and produce hydrogen. ${ }^{3,4}$ However, hydrogen is a flammable gas with an ignition energy of $0.03 \mathrm{~mJ}$. Even static electricity discharge could cause its ignition. ${ }^{4}$ In some engineering projects, the existence of hydrogen can present the risk of fire or explosion. For example, in wet dust removal systems used for the treatment of aluminium dust, the aluminium dust could react with water and produce hydrogen. Many hydrogen explosion accidents have occurred worldwide in wet dust removal systems, and these accidents resulted in property damage and casualties. ${ }^{5}$ According to NFPA484-2015, explosion-proof, anti-static and venting explosion measures should be adopted in wet dust removal systems. Because of the above safety-technical measures, the probability of hydrogen fire or explosion accidents could be rather low, which is why there is almost no research on the inhibition of aluminium and water reaction. However, when even these safety-technical measures are adopted, hydrogen fire or explosion problems in wet dust removal systems cannot be solved fundamentally. In the event of a hydrogen fire or an explosion in a wet dust removal system for the treatment of aluminium dust, the cost of the accident investigation and handling, medical injury

College of Resource and Civil Engineering, Northeastern University, Shenyang, 110819, China. E-mail: kaili_xu65@126.com

$\dagger$ Electronic supplementary information (ESI) available. See DOI: $10.1039 / \mathrm{c} 7 \mathrm{ra} 04787 \mathrm{~h}$ Based on the shrinking core model, Z. Y. Deng established the reaction mechanism model of the reaction between aluminium and water. ${ }^{6} \mathrm{H}$. Z. Wang reviewed the methods for producing hydrogen by using aluminium and aluminium alloys. ${ }^{4} \mathrm{~W}$. Z. Gai studied the effects of initial gas pressure, ${ }^{7}$ trace species in water, ${ }^{8}$ aluminium particle size and temperature ${ }^{1}$ on the reaction of aluminium and water. Important studies have identified the reaction mechanism, established the reaction mechanism model, which is based on the shrinking core model, and discussed the effects of different initial conditions on the reaction. Additionally, a series of methods that could promote the reaction have been proposed.,.$^{2,-14}$

Previous studies have focused on how to promote the reaction between aluminium particles and water. This work is concerned with how to inhibit the reaction. According to previous studies, ${ }^{\mathbf{6}, 15-17}$ the chemical reaction equations of the reaction are list below.

$$
\begin{gathered}
\mathrm{Al}_{2} \mathrm{O}_{3}+3 \mathrm{H}_{2} \mathrm{O} \rightarrow 2 \mathrm{Al}(\mathrm{OH})_{3} \\
2 \mathrm{Al}(\mathrm{OH})_{3}+2 \mathrm{Al} \rightarrow 2 \mathrm{Al}_{2} \mathrm{O}_{3}+3 \mathrm{H}_{2} \uparrow \\
2 \mathrm{Al}+6 \mathrm{H}_{2} \mathrm{O} \rightarrow 2 \mathrm{Al}(\mathrm{OH})_{3}+3 \mathrm{H}_{2} \uparrow
\end{gathered}
$$

A passive oxide film is formed on the aluminium particles' surface, which could inhibit the reaction between aluminium and water. However, when aluminium particles are placed in water, the hydration reaction occurs on the alumina protective 
layer, as shown in eqn (1). The hydration reaction produces hydroxide phases such as $\mathrm{Al}(\mathrm{OH})_{3}$. After the hydration reaction, the hydroxide phases could react with the aluminium core and generate hydrogen, as shown in eqn (2). Water molecules can also be transported through the aluminium hydroxide layer and react with the aluminium core directly, as shown in eqn (3). ${ }^{6}$

The reaction between aluminium and water is a form of metal corrosion. ${ }^{6,18}$ The aluminium matrix acts as an anode, and the anode reaction is shown in eqn (4). ${ }^{19}$ The $\mathrm{H}^{+}$in the solution acts as a cathode, and the cathodic reaction is shown in eqn (5)..$^{19,20}$ Oxygen dissolved in the solution may undergo a reduction reaction, generating $\mathrm{OH}^{-}$.

$$
\begin{gathered}
\mathrm{Al}-3 \mathrm{e} \rightarrow \mathrm{Al}^{3+} \\
2 \mathrm{H}^{+}+2 \mathrm{e} \rightarrow \mathrm{H}_{2} \uparrow \\
\mathrm{O}_{2}+2 \mathrm{H}_{2} \mathrm{O}+4 \mathrm{e} \rightarrow 4 \mathrm{OH}^{-}
\end{gathered}
$$

To prevent aluminium corrosion, trivalent chromium chemical conversion coating has been studied by many researchers. This method can also be used to prevent corrosion of a variety of metal slabs, such as aluminium, ${ }^{21,22}$ steel $^{23}$ and zinc slabs. ${ }^{24}$ Trivalent Cr coatings were first studied by Agarwala through the immersion of aluminium alloy in solutions containing $\mathrm{Cr}_{2}\left(\mathrm{SO}_{4}\right)_{3} \cdot{ }^{25,26} \mathrm{Y}$. Guo characterized the coating formed on AA2024-T3 after the trivalent chromium process treatment. ${ }^{27}$ H. C. Yu investigated the trivalent-chrome coating on 6063 aluminium alloy. ${ }^{21}$ The trivalent chromium process treatment methods mentioned above are used to solve the corrosion problem of metal slabs, and the solutions need to be acidic in order to remove impurities on the slab surface. ${ }^{\mathbf{2 6 , 2 8}}$ However, aluminium particles can produce hydrogen more rapidly under acidic conditions. Therefore, the trivalent chromium process treatment methods are not suitable for preventing the reaction between aluminium particles and water. This work improves upon the methods in order to directly soak aluminium dust in a solution containing trivalent chromium and inhibit the hydrogen production reaction. This improved method is referred to as the HIM. Through the HIM, the reaction between aluminium particles and water can be inhibited, and the problem of hydrogen fire or explosions in some engineering projects, such as wet dust removal systems for the treatment of aluminium dust, can be solved fundamentally.

\section{Experimental procedure}

An atomized aluminium powder production enterprise was chosen as the field research site. In this enterprise, the wet dust collection system was used to collect aluminium dust released into the workshop from the $20 \mu \mathrm{m}$ aluminium powder production line. The physical figure and the internal structure diagram of the wet dust collector are shown in ESI. $\dagger$

The aluminium dust deposited in the wet dust collector can react with water and produced hydrogen. When the concentration of hydrogen reaches the explosion limit (4-74\%) and encounters an ignition source, hydrogen fire or explosion accidents could occur. These accidents could cause damage to the wet dust collector and injure workers.

\subsection{The hydrogen inhibition experiment}

To systematically study the effect of the HIM on the inhibition of the aluminium particle and water reaction, hydrogen production inhibition experiments were carried out in the laboratory. The detail information of the aluminium and water reaction tester is shown in ESI. $\dagger$

Aluminium dust collected from the dust suction hole on the wet dust collector was used in the experiment. $2 \mathrm{~g}$ aluminium dust was used in each experiment. $\mathrm{CrK}\left(\mathrm{SO}_{4}\right)_{2} \cdot 12 \mathrm{H}_{2} \mathrm{O}$ (Analytical regent grade, Sinopharm Chemical Reagent Co., Ltd., Shanghai, China) and deionized water were applied to prepare a certain concentration of the solution. The experiments were carried out in an aluminium and water reaction tester, as shown in ESI. $\dagger$ The initial temperature and pressure for each experiment were set at $50{ }^{\circ} \mathrm{C}$ and $100 \mathrm{kPa}$, respectively. In each experiment, 200 $\mathrm{mL}$ solution was added to the reactor. The aluminium particles react with water, producing only hydrogen. Thus, the gas pressure $P$ is proportional to the amount of generated hydrogen $n$. The change in the mole of the generated hydrogen can be characterized by the change of the pressure in the reactor.

For different groups of experiments, hydrogen evolution $\alpha$ is used to represent the extent of the reaction, as shown in ESI. $\dagger$

\subsection{Characterization experiment}

To better understand the phases of the reaction product, the aluminium powder samples reacted with $0.0754 \mathrm{~g} \mathrm{L^{-1 }}$ $\mathrm{CrK}\left(\mathrm{SO}_{4}\right)_{2} \cdot 12 \mathrm{H}_{2} \mathrm{O}$ solution were characterized by X-ray diffraction (XRD) (MPDDY2094, PANalytical B.V.). The X-ray source with a copper cathode was operated at approximately $40 \mathrm{kV}$ and $40 \mathrm{~mA}$. The samples were scanned over the $2 \theta$ interval between 5 and $90^{\circ}$ in $0.01^{\circ}$ steps and at an angular speed of $0.02^{\circ} \mathrm{s}^{-1}$.

Scanning electron microscopy (SEM) (ULTRA PLUS, Zeiss Microscope Company, Germany) was used to characterize the appearance of the aluminium particles. The original aluminium particles and aluminium particles reacted with different solutions were characterized. Energy-dispersive X-ray spectroscopy (EDS) was used to characterize the distribution of $\mathrm{Cr}$ in the film on the aluminium particles treated by the HIM. A laser diffraction analyser (Microtrac s3500) was used to determine the size distribution of the aluminium powder.

The surface films on the aluminium particles reacted with $0.0754 \mathrm{~g} \mathrm{~L}^{-1} \mathrm{CrK}\left(\mathrm{SO}_{4}\right)_{2} \cdot 12 \mathrm{H}_{2} \mathrm{O}$ solution were analysed by X-ray photoelectron spectroscopy (XPS) (ESCALAB 250Xi). Nonmonochromatic $\mathrm{Al} \mathrm{K} \alpha \mathrm{X}$-ray radiation $(h \nu=1468.6 \mathrm{eV})$ was used for excitation; the aluminium twin anode was powered at $14 \mathrm{kV}$ and $20 \mathrm{~mA}$. The photoelectron take-off angle was $45^{\circ}$. The base pressure was kept below $10^{-9}$ mbar. The spectrometer was calibrated relative to the $\mathrm{C} 1 \mathrm{~s}$ peak at $284.8 \mathrm{eV}$. The background intensity was subtracted from the spectra using the Shirley method. Values for the relevant core-level binding energies were obtained from curve fitting of the photoelectron emission lines using a symmetrical Gaussian-Lorentzian function. Two 
components could be fitted for chromium: Al-O bond (73.7$74.5 \mathrm{eV})^{29,30}$ and $\mathrm{Cr}(\mathrm{OH})_{3}(577.3 \pm 0.2 \mathrm{eV}) \cdot{ }^{31-33}$

\section{Results and discussion}

\subsection{Characterization of aluminium dust}

Fig. 1 shows an SEM image of the aluminium dust. The surface of the aluminium dust is smooth and compact. The aluminium dust particles are basically spherical. Fig. 2 shows the results of the particle size analysis. The size and volumetric distributions of particles were determined using a laser diffraction analyser and were characterized by $d_{10}, d_{50}, d_{90}, M_{\mathrm{n}}, M_{\mathrm{v}}$ and $M_{\mathrm{a}}$, which are presented separately in Fig. 2. Most of the particles are concentrated at a size of approximately $20 \mu \mathrm{m}$.

\subsection{The hydrogen production inhibition experiment}

According to the research of W. Z. Gai, ${ }^{1}$ when temperature is the only variable parameter in the experiment, the hydrogen production will be promoted by increasing the temperature. If the HIM proposed in this work can effectively inhibit the reaction between aluminium and water at a higher temperature, the inhibitory effect can also perform at a lower temperature. According to the field survey, taking the wet dust collector shown in ESI $\dagger$ as an example, the temperature in the wet dust collector does not exceed $25{ }^{\circ} \mathrm{C}$. The accumulation of hydrogen occurs when the fan of the wet dust collector is stopped, and the pressure inside the wet dust collector at this time is atmospheric pressure. Thus, the initial temperature of the inhibition experiment was set to $50{ }^{\circ} \mathrm{C}$ and the initial pressure was set to $100 \mathrm{kPa}$. $\mathrm{CrK}\left(\mathrm{SO}_{4}\right)_{2} \cdot 12 \mathrm{H}_{2} \mathrm{O}$ samples of different masses were weighed separately by using an electronic balance in order to configure different concentrations of $\mathrm{CrK}\left(\mathrm{SO}_{4}\right)_{2} \cdot 12 \mathrm{H}_{2} \mathrm{O}$ solutions.

Fig. 3 shows the hydrogen production curve of aluminium particles reacted with different concentrations of $\mathrm{CrK}\left(\mathrm{SO}_{4}\right)_{2}$ $\cdot 12 \mathrm{H}_{2} \mathrm{O}$ solutions. Aluminium particles could react with the $\mathrm{CrK}\left(\mathrm{SO}_{4}\right)_{2} \cdot 12 \mathrm{H}_{2} \mathrm{O}$ solutions whose concentration is less than or equal to $0.032 \mathrm{~g} \mathrm{~L}^{-1}$, and the hydrogen production curves are significantly different. The hydrogen evolution $\alpha$ is no more than 0.6, indicating that the reaction between aluminium particles and water did not completely consume the $2 \mathrm{~g}$ of

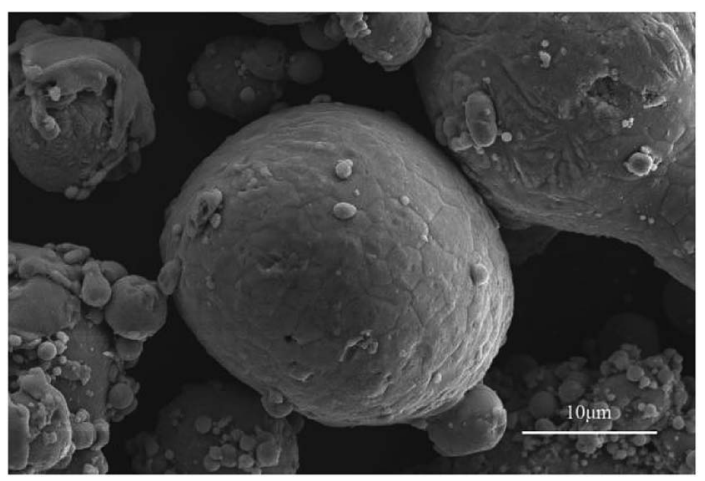

Fig. 1 An SEM image of the aluminium dust.

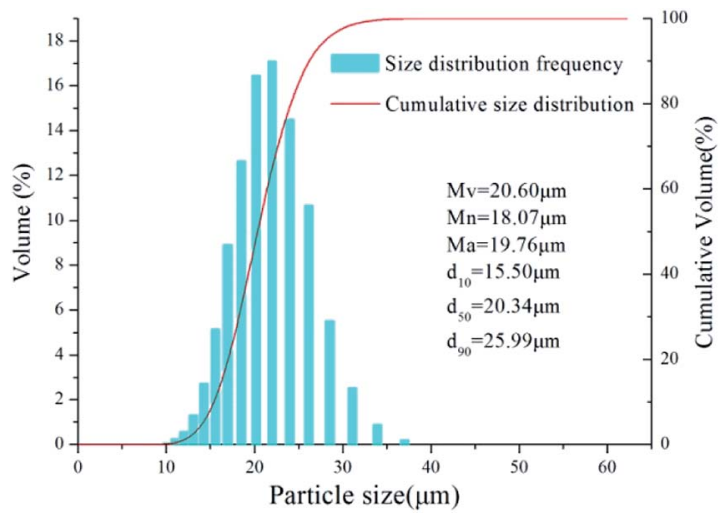

Fig. 2 Particle size distribution.

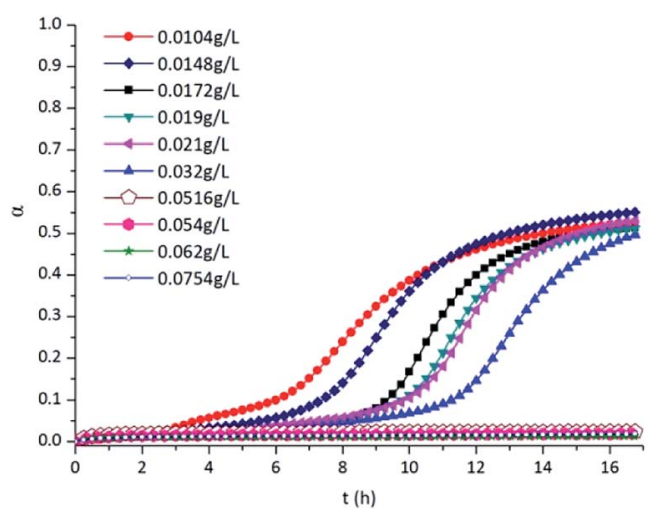

Fig. 3 Hydrogen production curves of aluminium powder reacting with $\mathrm{CrK}\left(\mathrm{SO}_{4}\right)_{2} \cdot 12 \mathrm{H}_{2} \mathrm{O}$ solution.

aluminium powder added to the tester. It can be seen that the reaction did not start immediately after the aluminium particles contacted the $\mathrm{CrK}\left(\mathrm{SO}_{4}\right)_{2} \cdot 12 \mathrm{H}_{2} \mathrm{O}$ solutions. This was due to the existence of a passive oxide film. After the hydration reaction of the $\mathrm{Al}_{2} \mathrm{O}_{3}$ film finished, the aluminium core could then react with water molecules or the $\mathrm{Al}(\mathrm{OH})_{3}$ layer to generate hydrogen, as shown in eqn (1)-(3). As the concentration of the solution increased, the hydrogen evolution $\alpha$ at the same time decreased gradually, indicating that the reaction between aluminium particles and the $\mathrm{CrK}\left(\mathrm{SO}_{4}\right)_{2} \cdot 12 \mathrm{H}_{2} \mathrm{O}$ solution was inhibited to varying degrees. When the concentration of $\mathrm{CrK}\left(\mathrm{SO}_{4}\right)_{2} \cdot 12 \mathrm{H}_{2} \mathrm{O}$ solutions reached $0.0516 \mathrm{~g} \quad \mathrm{~L}^{-1}$, the reaction between aluminium particles and water was inhibited. The hydrogen evolution $\alpha$ was nearly zero. There was almost no difference in the inhibition effect as the concentration of $\mathrm{CrK}\left(\mathrm{SO}_{4}\right)_{2} \cdot 12 \mathrm{H}_{2} \mathrm{O}$ solutions further increased to $0.0754 \mathrm{~g} \mathrm{~L}^{-1}$.

\subsection{SEM-EDS}

Three kinds of aluminium powder samples were selected: (1) original aluminium powder samples; (2) aluminium powder samples after reaction with the $0.0172 \mathrm{~g} \mathrm{~L}^{-1} \mathrm{CrK}\left(\mathrm{SO}_{4}\right)_{2} \cdot 12 \mathrm{H}_{2} \mathrm{O}$ solution; and (3) aluminium powder samples after reaction with the $0.0754 \mathrm{~g} \mathrm{~L}^{-1} \mathrm{CrK}\left(\mathrm{SO}_{4}\right)_{2} \cdot 12 \mathrm{H}_{2} \mathrm{O}$ solution. Fig. 1 shows the SEM image of original aluminium powder. Fig. 4a shows the 

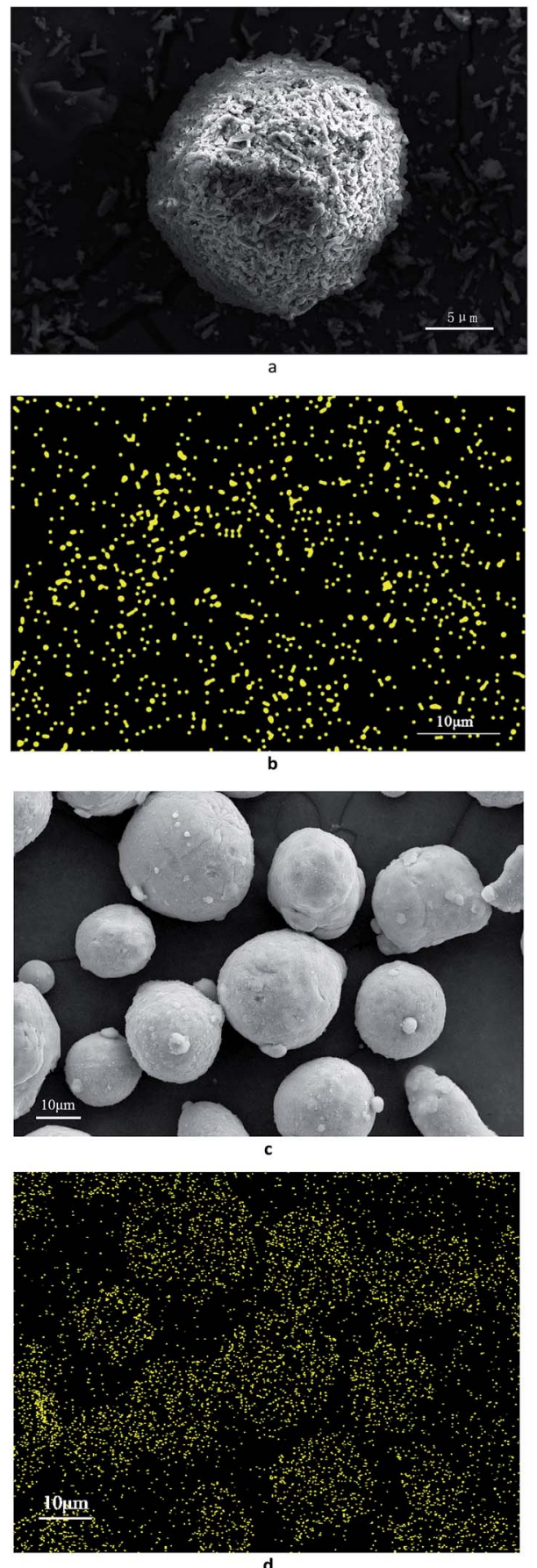

Fig. 4 Aluminium powder reacted with different concentrations of $\mathrm{CrK}\left(\mathrm{SO}_{4}\right)_{2} \cdot 12 \mathrm{H}_{2} \mathrm{O}$ solution ((a) the SEM image of aluminium powder after reaction with $0.0172 \mathrm{~g} \mathrm{~L}^{-1} \mathrm{CrK}\left(\mathrm{SO}_{4}\right)_{2} \cdot 12 \mathrm{H}_{2} \mathrm{O}$ solution (b) the EDS result of aluminium powder after reaction with $0.0172 \mathrm{~g} \mathrm{~L}^{-1}$ $\mathrm{CrK}\left(\mathrm{SO}_{4}\right)_{2} \cdot 12 \mathrm{H}_{2} \mathrm{O}$ solution (c) the SEM image of aluminium powder after reaction with $0.0754 \mathrm{~g} \mathrm{~L}^{-1} \mathrm{CrK}\left(\mathrm{SO}_{4}\right)_{2} \cdot 12 \mathrm{H}_{2} \mathrm{O}$ solution (d) the EDS result of aluminium powder after reaction with $0.0754 \mathrm{~g} \mathrm{~L}^{-1}$ $\mathrm{CrK}\left(\mathrm{SO}_{4}\right)_{2} \cdot 12 \mathrm{H}_{2} \mathrm{O}$ solution).

SEM image of aluminium powder samples after reaction with the $0.0172 \mathrm{~g} \mathrm{~L}^{-1} \mathrm{CrK}\left(\mathrm{SO}_{4}\right)_{2} \cdot 12 \mathrm{H}_{2} \mathrm{O}$ solution. It can be seen that the surface of aluminium particles after reaction with the $0.0172 \mathrm{~g} \mathrm{~L}^{-1} \mathrm{CrK}\left(\mathrm{SO}_{4}\right)_{2} \cdot 12 \mathrm{H}_{2} \mathrm{O}$ solution is very rough. The EDS imagine of $\mathrm{Cr}$ distribution on aluminium particles after reaction with $0.0172 \mathrm{~g} \mathrm{~L}^{-1} \mathrm{CrK}\left(\mathrm{SO}_{4}\right)_{2} \cdot 12 \mathrm{H}_{2} \mathrm{O}$ solution is shown in Fig. $4 \mathrm{~b}$. The results in Fig. $4 \mathrm{a}$ and $\mathrm{b}$, show no obvious relationship between the $\mathrm{Cr}$ distribution and the aluminium particles. Fig. $4 \mathrm{c}$ is the SEM image of aluminium particles after reaction with the $0.0754 \mathrm{~g} \mathrm{~L}^{-1} \mathrm{CrK}\left(\mathrm{SO}_{4}\right)_{2} \cdot 12 \mathrm{H}_{2} \mathrm{O}$ solution. It can be seen that the aluminium particles' surface was smooth and compact. According to the hydrogen evolution curve shown in Fig. 3, it can be seen that the hydrogen production reaction was inhibited. The distribution of $\mathrm{Cr}$ on aluminium particles was analysed by the EDS. The EDS result of aluminium powder samples after reaction with the $0.0754 \mathrm{~g} \mathrm{~L}^{-1} \mathrm{CrK}\left(\mathrm{SO}_{4}\right)_{2} \cdot 12 \mathrm{H}_{2} \mathrm{O}$ solution is shown in Fig. 4d. Through the comparison of Fig. 4c and $\mathrm{d}$, it can be seen that Cr evenly distributed on the surface of the aluminium particles.

\subsection{XRD}

XRD was used to identify the product of the hydrogen inhibition reaction. Fig. 5 shows that $\mathrm{Al}(\mathrm{OH})_{3}$ and $\mathrm{Cr}(\mathrm{OH})_{3}$ were generated after the aluminium powder reacted with the $0.0754 \mathrm{~g} \mathrm{~L}^{-1}$ $\mathrm{CrK}\left(\mathrm{SO}_{4}\right)_{2} \cdot 12 \mathrm{H}_{2} \mathrm{O}$ solution. According to Bunker, ${ }^{34}$ when aluminium powder is put in water, the oxide film on aluminium particles is hydrated. As shown in eqn (1), one Al-O-Al linkage of $\mathrm{Al}_{2} \mathrm{O}_{3}$ is broken to form two $\mathrm{Al}-\mathrm{OH}$ species. Aluminol groups ( $\equiv \mathrm{Al}-\mathrm{OH})$ form on the oxide surface. The presence of $\mathrm{Al}(\mathrm{OH})_{3}$ in the XRD results confirmed the hydration reaction of the passive oxide film on aluminium particles. $\mathrm{Cr}(\mathrm{OH})_{3}$ is a precipitate that can be uniformly attached to the aluminium particles. According to H. X. You ${ }^{35}$ and Carlos E. Barrera-Diaz, ${ }^{36} \mathrm{Cr}^{3+}$ can react with the water molecules in the solution, combining with the $\mathrm{OH}^{-}$in the solution or the aluminol group's to produce $\mathrm{Cr}(\mathrm{OH})_{3} \cdot \mathrm{Cr}(\mathrm{OH})_{3}$ is one of the main components of the inhibition film, which can prevent contact between water molecules and the aluminium matrix. The chemical reaction equation of the reaction is shown in eqn (7).

$$
\mathrm{Cr}^{3+}+3 \mathrm{H}_{2} \mathrm{O} \rightarrow \mathrm{Cr}(\mathrm{OH})_{3} \downarrow+3 \mathrm{H}^{+}
$$

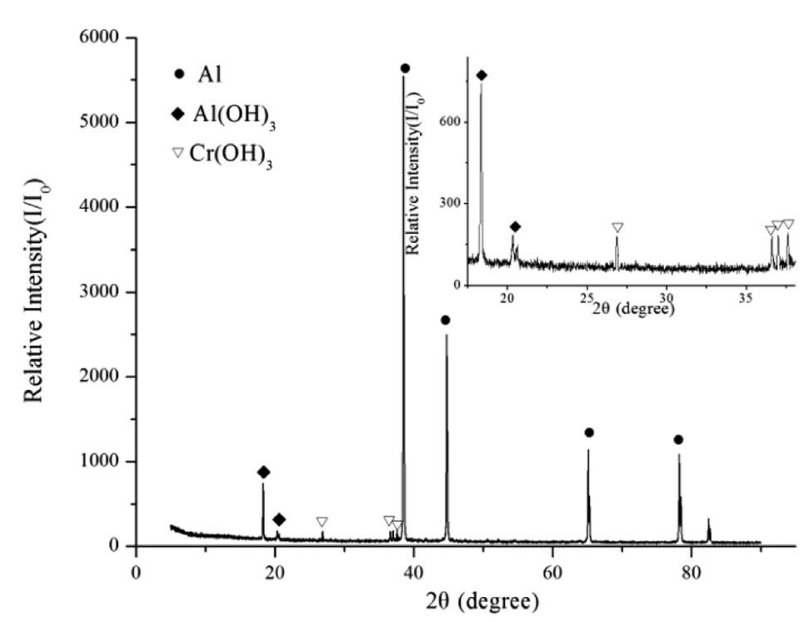

Fig. 5 XRD pattern of aluminium particles after reaction with the $0.0754 \mathrm{~g} \mathrm{~L}^{-1} \mathrm{CrK}\left(\mathrm{SO}_{4}\right)_{2} \cdot 12 \mathrm{H}_{2} \mathrm{O}$ solution. 
As the inhibition reaction produced very little $\mathrm{Al}(\mathrm{OH})_{3}$ and $\mathrm{Cr}(\mathrm{OH})_{3}$, the diffraction peaks are very weak. However, the peak corresponding to metallic $\mathrm{Al}$ is very high, indicating that the content of pure $\mathrm{Al}$ is rather high. In other words, the metallic aluminium matrix was not consumed in the $0.0754 \mathrm{~g} \mathrm{~L}^{-1}$ $\mathrm{CrK}\left(\mathrm{SO}_{4}\right)_{2} \cdot 12 \mathrm{H}_{2} \mathrm{O}$ solution, and the reaction was inhibited, consistent with the hydrogen production curve shown in Fig. 3.

\section{$3.5 \quad$ XPS}

XPS provides information on the valence of $\mathrm{Al}$ and $\mathrm{Cr}$ in the inhibition film. Fig. 6 is the result of the $\mathrm{Al} \mathrm{2p}$ spectra of aluminium dust after reaction with the $0.0754 \mathrm{~g} \mathrm{~L}^{-1}$ $\mathrm{CrK}\left(\mathrm{SO}_{4}\right)_{2} \cdot 12 \mathrm{H}_{2} \mathrm{O}$ solution. As seen in Fig. 6 , there is only one peak with a binding energy of $74 \mathrm{eV}$. This peak is attribute to the $\mathrm{Al}-\mathrm{O}$ bond..$^{29,30}$ The reason for the existence of the $\mathrm{Al}-\mathrm{O}$ bond in the inhibition film is the hydration reaction of the passive oxide film on aluminium particles. $\mathrm{Al}_{2} \mathrm{O}_{3}$ reacted with water and generated $\mathrm{Al}(\mathrm{OH})_{3}$, as shown in eqn (1) and consistent with the XRD result. Fig. 7 shows the Cr 2 p spectra result of aluminium dust after reaction with the $0.0754 \mathrm{~g} \mathrm{~L}^{-1} \mathrm{CrK}\left(\mathrm{SO}_{4}\right)_{2} \cdot 12 \mathrm{H}_{2} \mathrm{O}$ solution. There are two peaks in Fig. 7; one is the Cr $2 \mathrm{p} 1 / 2$ peak, and the other is the $\mathrm{Cr} 2 \mathrm{p} 3 / 2$ peak. According to, ${ }^{31-33}$ the peak with a binding energy of $577.3 \pm 0.2 \mathrm{eV}$ is attributed to $\mathrm{Cr}-\mathrm{OH}$. The XPS results show that the $\mathrm{Cr}^{3+}$ peak energy is $577.4 \mathrm{eV}$. Thus, it can be proved that $\mathrm{Cr}(\mathrm{OH})_{3}$ covered the surface of the aluminium particles. The XPS result is also consistent with the XRD result.

The percentage of elemental distribution was also analyzed by the XPS. The content of $\mathrm{O}$ in the inhibition film is $78.40 \%$. And $\mathrm{O}$ is the most abundant element in the inhibition film. The percentage of $\mathrm{Al}$ in the inhibition film is $15.44 \%$. While the percentage of $\mathrm{Cr}$ is $6.16 \%$. The content of $\mathrm{Al}$ and $\mathrm{Cr}$ in the film is limited. The result consistent with the weak peaks of $\mathrm{Al}(\mathrm{OH})_{3}$ and $\mathrm{Cr}(\mathrm{OH})_{3}$ shown in Fig. 5 .

In addition to the formation of $\mathrm{Cr}(\mathrm{OH})_{3}$, there is another reason for the even distribution of $\mathrm{Cr}$ on the inhibition film. According to K. Csobán's research, $\mathrm{Cr}^{3+}$ can react with aluminol groups. ${ }^{37}$ The reaction equations are listed below. $\mathrm{Cr}^{3+}$ displaces

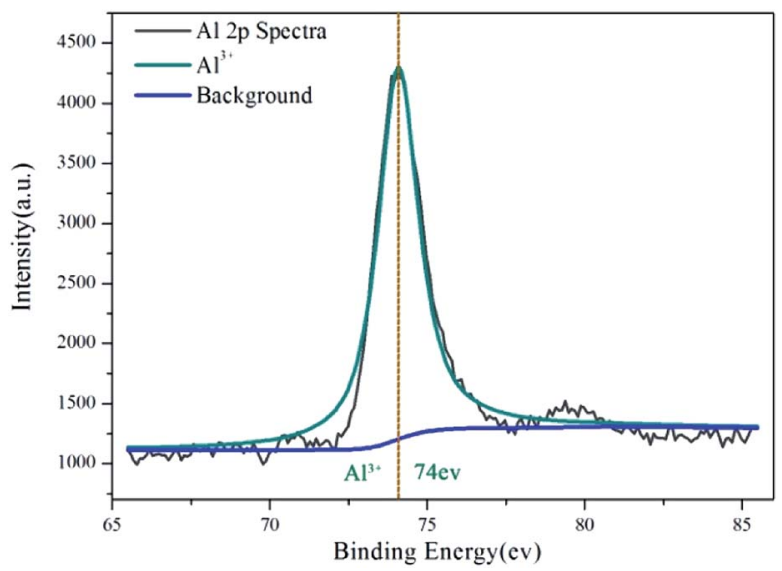

Fig. $6 \mathrm{Al} 2 \mathrm{p}$ spectra for the inhibition film after aluminium powder reacted with the $0.0754 \mathrm{~g} \mathrm{~L}^{-1} \mathrm{CrK}\left(\mathrm{SO}_{4}\right)_{2} \cdot 12 \mathrm{H}_{2} \mathrm{O}$ solution.

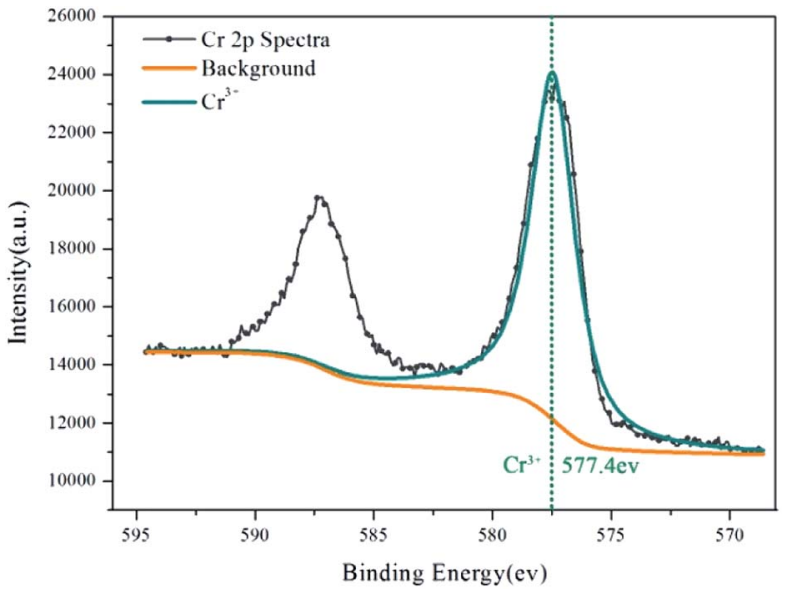

Fig. $7 \mathrm{Cr} 2 \mathrm{p}$ spectra for the inhibition film after aluminium powder reacted with the $0.0754 \mathrm{~g} \mathrm{~L}^{-1} \mathrm{CrK}\left(\mathrm{SO}_{4}\right)_{2} \cdot 12 \mathrm{H}_{2} \mathrm{O}$ solution.

a proton from $\equiv \mathrm{Al}-\mathrm{OH}$ groups and generates $\mathrm{AlOCr}^{2+}$. Then, $\mathrm{AlOCr}^{2+}$ absorbs $\mathrm{OH}^{-}$in the solution, producing $\mathrm{AlOCr}(\mathrm{OH})^{+}$ and $\operatorname{AlOCr}(\mathrm{OH})_{2}$. These reactions, shown in eqn (8)-(10), were another reason for $\mathrm{Cr}$ evenly distributing on the aluminium particles' surface.

$$
\begin{gathered}
\equiv \mathrm{AlOH}+\mathrm{Cr}^{3+} \rightarrow \mathrm{AlOCr}^{2+}+\mathrm{H}^{+} \\
\equiv \mathrm{AlOH}+\mathrm{Cr}^{3+}+\mathrm{H}_{2} \mathrm{O} \rightarrow \mathrm{AlOCr}(\mathrm{OH})^{+}+2 \mathrm{H}^{+} \\
\equiv \mathrm{AlOH}+\mathrm{Cr}^{3+}+2 \mathrm{H}_{2} \mathrm{O} \rightarrow \operatorname{AlOCr}(\mathrm{OH})_{2}+3 \mathrm{H}^{+}
\end{gathered}
$$

\section{Physicochemical mechanisms}

According to previous studies, the reaction of aluminium dust with oxygen in the air causes a layer of protective film of alumina to form around the external surface of aluminium particles. This film will prevent the further reaction between aluminium particles and water. ${ }^{15}$ When aluminium particles are present in water, with the increase of immersion time, the alumina protective film will gradually react with water to form aluminium hydrate. As schematically shown in Fig. 8, at this stage, the thickness of the oxide film does not change until the entire oxide film is hydrated to form an $\mathrm{Al}(\mathrm{OH})_{3}$ film, consistent with the $\mathrm{Al}(\mathrm{OH})_{3}$ diffraction peaks shown in Fig. 5 and the XPS result shown in Fig. 6. The $\mathrm{Al}(\mathrm{OH})_{3}$ film can also react with the aluminium core to regenerate the alumina and water molecules, which can react with the aluminium core to produce hydrogen. Water molecules can be transported to the aluminium core through the internal diffusion of the $\mathrm{Al}(\mathrm{OH})_{3}$ film. ${ }^{38}$ As shown in Fig. 9, ellipsoidal hydrogen bubbles are uniformly arranged around the aluminium core under the $\mathrm{Al}(\mathrm{OH})_{3}$ film. With the accumulation of hydrogen, the $\mathrm{Al}(\mathrm{OH})_{3}$ film suffers from increasing tension. When the tension is larger than the critical tension of the $\mathrm{Al}(\mathrm{OH})_{3}$, the film will rupture, and the hydrogen is then released. Then, the aluminium core will react with water directly. The reaction will then occur more quickly. 


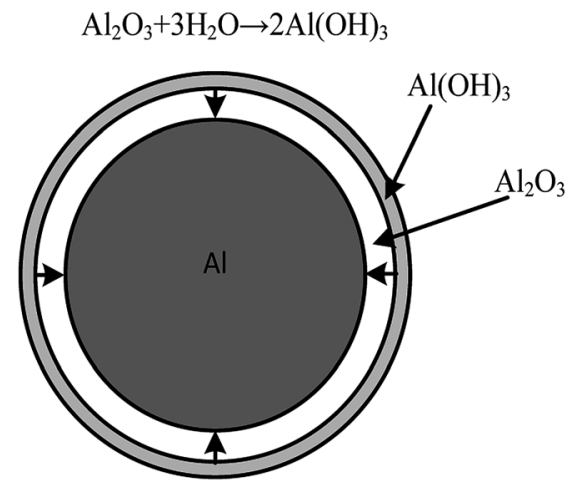

Fig. 8 The hydration reaction of the oxide film on the surface of aluminium particles.

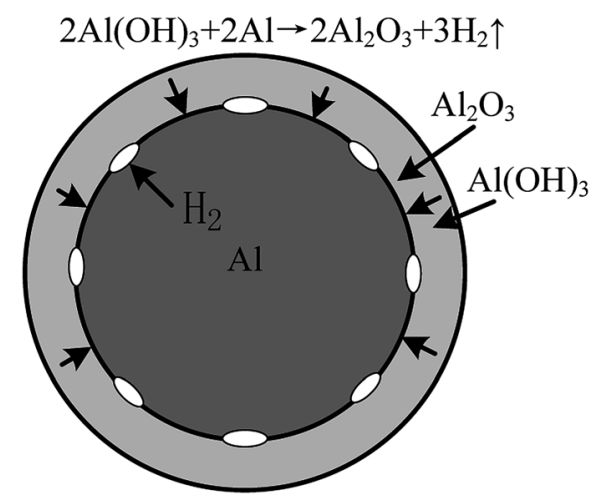

Fig. 9 The reaction of hydrogen production.

When the concentration of the $\mathrm{CrK}\left(\mathrm{SO}_{4}\right)_{2} \cdot 12 \mathrm{H}_{2} \mathrm{O}$ solution was equal to or higher than $0.062 \mathrm{~g} \mathrm{~L}^{-1}$, according to Fig. 3, the reaction between aluminium and water was inhibited. Due to the higher concentration of the $\mathrm{CrK}\left(\mathrm{SO}_{4}\right)_{2} \cdot 12 \mathrm{H}_{2} \mathrm{O}$ solution, there was enough $\mathrm{Cr}^{3+}$ in the solution to react with water and generate more $\mathrm{Cr}(\mathrm{OH})_{3}$ precipitation in a short time, as shown in eqn (7). The inhibition film, shown in Fig. 10, could also inhibit the transportation of water molecules from the solution to the surface of the aluminium core. Thus, the reaction between aluminium particles and water is inhibited. This

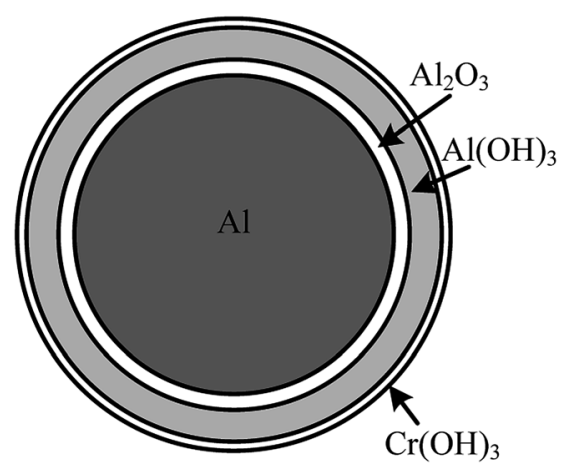

Fig. 10 The inhibition film on aluminium particles. means that there is no hydrogen remaining, and the problem of hydrogen fire or explosion is solved fundamentally.

\section{Chemical kinetic model of hydrogen production inhibition}

The physicochemical mechanism was established based on the shrinking core model. Gai W.-Z. validated the application of the shrinking core in the reaction of aluminium powder with water. ${ }^{1}$ Soler L. ${ }^{39}$ studied the reaction of aluminium powder in $\mathrm{Na}_{2} \mathrm{SnO}_{3}$ solution, and the kinetic model of the chemical reaction was also established by applying the shrinking core model. The hydrogen evolution $\alpha$ and reaction rate should fit eqn (11) during the hydrogen generation period. Detail derivation of the eqn (11) can be found in Levenspiel ${ }^{40}$ or in ESI. $\dagger$

$$
1-(1-\alpha)^{1 / 3}=k t
$$

$k$ - rate constant, $\mathrm{h}^{-1} \cdot t$ - reaction time, $\mathrm{h}$.

The curve corresponding to the aluminium powder reacted with the $0.0104 \mathrm{~g} \mathrm{~L}^{-1} \mathrm{CrK}\left(\mathrm{SO}_{4}\right)_{2} \cdot 12 \mathrm{H}_{2} \mathrm{O}$ solution was selected as an example for curve fitting; the fitting results are shown in Fig. 11. The reaction of aluminium particles in the $\mathrm{CrK}\left(\mathrm{SO}_{4}\right)_{2}-$ $\cdot 12 \mathrm{H}_{2} \mathrm{O}$ solution was confirmed to be controlled by the surface chemical reaction. After the start of the experiment, the curve shown in Fig. 11 is very gentle. During this period of time, the alumina protective film will gradually react with water to form aluminium hydrate. The reaction was shown in eqn (1). At the same time $\mathrm{Cr}^{3+}$ in the solution will start to react with water molecules or the aluminol group's to produce $\mathrm{Cr}(\mathrm{OH})_{3}$ or $\operatorname{AlOCr}(\mathrm{OH})_{2}$. The reactions are shown in eqn (7)-(10). If the concentration of $\mathrm{CrK}\left(\mathrm{SO}_{4}\right)_{2} \cdot 12 \mathrm{H}_{2} \mathrm{O}$ solution is high enough to form an inhibition film covered on the aluminium particles, then the hydrogen production reaction will be inhibited. But when the concentration of $\mathrm{CrK}\left(\mathrm{SO}_{4}\right)_{2} \cdot 12 \mathrm{H}_{2} \mathrm{O}$ solution is not enough, the hydrogen production reactions will begin. After the entire oxide film is hydrated to form an $\mathrm{Al}(\mathrm{OH})_{3}$ film, reactions shown in eqn (2) and (3) take places. That is the reason for the risen of the curve. The chemical reaction rate constant $k$ was

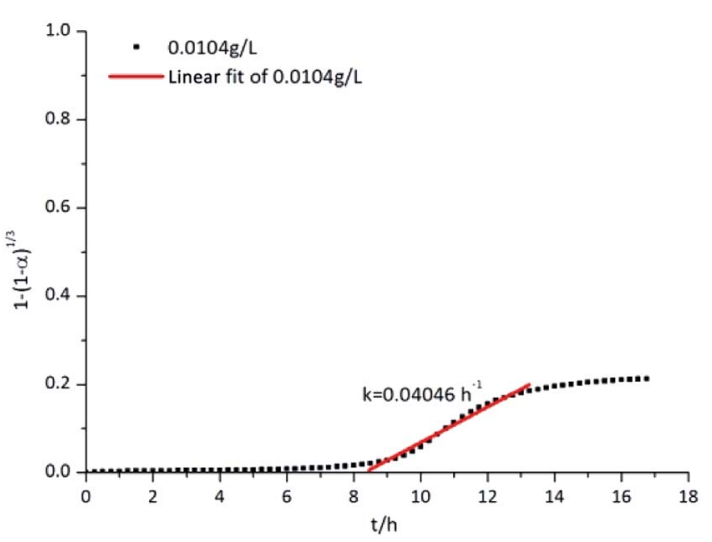

Fig. 11 Chemical kinetics curve of aluminium powder reacted with the $0.0104 \mathrm{~g} \mathrm{~L}^{-1} \mathrm{CrK}\left(\mathrm{SO}_{4}\right)_{2} \cdot 12 \mathrm{H}_{2} \mathrm{O}$ solution. 
calculated to be $0.04046 \mathrm{~h}^{-1}$. The rate constants $k$ from different experiments are shown in Table 1 . It can be seen that the rate constant $k$ decreases gradually with the increase of the $\mathrm{CrK}\left(\mathrm{SO}_{4}\right)_{2} \cdot 12 \mathrm{H}_{2} \mathrm{O}$ solutions' concentration. That is because as the concentration of the solutions' increases, the inhibition film gradually forms on the surface of aluminium particles'. By the comparison of Fig. $4 \mathrm{~b}$ and $\mathrm{d}$, it can be seen that as the increasing of $\mathrm{CrK}\left(\mathrm{SO}_{4}\right)_{2} \cdot 12 \mathrm{H}_{2} \mathrm{O}$ solutions' concentration, an inhibition film containing uniform $\mathrm{Cr}$ formed on the aluminium particles. The reaction between aluminium particles and $\mathrm{CrK}\left(\mathrm{SO}_{4}\right)_{2} \cdot 12 \mathrm{H}_{2} \mathrm{O}$ solution was inhibited as the inhibition film was covered on the aluminium particles' surface. The inhibition film stopped the transportation of water molecules to the $\mathrm{Al}_{2} \mathrm{O}_{3}$ film and the aluminium core.

\section{Analysis of economic input}

According to the field survey of the atomized aluminium powder production enterprise and results of hydrogen inhibition experiments, the economic input was analyzed. Hydrogen concentration sensors and alarm device, explosion-proof electrical components and a pressure-relief device were installed on the wet dust collector. The design life of the safety-technical equipment system is 10 years. The hydrogen concentration sensors and the pressure relief device must be tested every year. The fan works $24 \mathrm{~h}$ per day to remove hydrogen from the wet dust collector. When the HIM is used, hydrogen will no longer exist in the wet dust collector. So there is no necessary to install any safety-technical device. The fan only has to work during the wet dust collector operation, which is approximately $8 \mathrm{~h}$ a day, thus using less electrical energy. 865, $488 \mathrm{~g}$ of aluminium dust will be sucked into the wet dust collector over the design life time of the safety-technical system. The total economic input over 10 years for the safety-technical device installed on the wet dust removal system is $\$ 143121.19$, whereas the total economic input of the HIM is $\$ 37$ 694.52. If no hydrogen fire or explosion accidents occur during the design lifetime of the safetytechnical system, using the HIM could save \$105 426.67. However, if a hydrogen explosion accident occurs, the wet dust removal system could be damaged, and workers could be

Table 1 Change in the rate constant

$\mathrm{CrK}\left(\mathrm{SO}_{4}\right)_{2} \cdot 12 \mathrm{H}_{2} \mathrm{O}$ solution

Concentration $\mathrm{g}$

$\mathrm{L}^{-1}$

$k / h^{-1}$

0.0104

0.0148

0.0172

0.019

0.021

0.032

0.0516

0.054

0.062

0.0754 injured or killed. Accident relief, plant and equipment maintenance, accident investigation, casualty compensation, etc. can be expensive, depending on the seriousness of the accident. The HIM can inhibit hydrogen generation, eliminating the risk of a hydrogen explosion accident.

\section{Conclusions}

Aluminium particles could react with water and produce hydrogen. In an industrial site, such as a wet dust removal system for the treatment of aluminium dust, the existence of hydrogen could present the risk of fire or explosion. The HIM was proposed to inhibit the reaction between aluminium particles and water. Thus, the problem of hydrogen fire or explosion could be solved fundamentally. The surface of the original aluminium particles is smooth and compact, but after reaction with the $0.0172 \mathrm{~g} \mathrm{~L}^{-1} \mathrm{CrK}\left(\mathrm{SO}_{4}\right)_{2} \cdot 12 \mathrm{H}_{2} \mathrm{O}$ solution, the surface became very rough. After being immersed in the $0.0754 \mathrm{~g} \mathrm{~L}^{-1} \mathrm{CrK}\left(\mathrm{SO}_{4}\right)_{2} \cdot 12 \mathrm{H}_{2} \mathrm{O}$ solution, the surface was smooth and dense. According to the EDS results, a Cr-rich film was formed on the surface of aluminium particles after reacting with the $0.0754 \mathrm{~g} \mathrm{~L}^{-1} \mathrm{CrK}\left(\mathrm{SO}_{4}\right)_{2} \cdot 12 \mathrm{H}_{2} \mathrm{O}$ solution. The inhibition film could effectively prevent the reaction between aluminium particles and water. The results of XRD and XPS shows that the main components of the inhibition film were $\mathrm{Al}(\mathrm{OH})_{3}$ and $\mathrm{Cr}(\mathrm{OH})_{3}$. The physicochemical mechanism of the reaction was analysed. There were two reasons for the formation of the inhibition film. One reason is the hydration reaction of aluminium particle oxides. The second reason is that $\mathrm{Cr}^{3+}$ reacted with $\mathrm{OH}^{-}$in the solution and generated $\mathrm{Cr}(\mathrm{OH})_{3}$ precipitate. According to the hydrogen production inhibition experiment, when the concentration of $\mathrm{CrK}\left(\mathrm{SO}_{4}\right)_{2} \cdot 12 \mathrm{H}_{2} \mathrm{O}$ solution was at least $0.062 \mathrm{~g} \mathrm{~L}^{-1}$, the reaction between aluminium particles and water could be inhibited. The cost of the HIM is much lower than that of the installed safety-technical system. The problem of hydrogen fire or explosion accident in the wet dust removal system can thus be solved fundamentally.

\section{Acknowledgements}

We would like to express our gratitude to the editor and the reviewers for suggestions and comments, which helped to improve the quality of this paper.

\section{Notes and references}

1 W.-Z. Gai, W.-H. Liu, Z.-Y. Deng and J.-G. Zhou, Int. J. Hydrogen Energy, 2012, 37, 13132-13140.

2 J. Macanás, L. Soler, A. M. Candela, M. Muñoz and J. Casado, Energy, 2011, 36, 2493-2501.

3 Z.-Y. Deng, Y.-B. Tang, L.-L. Zhu, Y. Sakka and J. Ye, Int. J. Hydrogen Energy, 2010, 35, 9561-9568.

4 H. Z. Wang, D. Y. C. Leung, M. K. H. Leung and M. Ni, Renewable Sustainable Energy Rev., 2009, 13, 845-853.

5 S. J. Zhong, N. Miao and H. Y. Liu, Modern Occupational Safety, 2014, 10, 26-29. 
6 Z. Y. Deng, J. M. F. Ferreira, Y. Tanaka and J. Ye, J. Am. Ceram. Soc., 2007, 90, 1521-1526.

7 W.-Z. Gai and Z.-Y. Deng, Int. J. Hydrogen Energy, 2014, 39, 13491-13497.

8 W. Z. Gai and Z. Y. Deng, J. Power Sources, 2014, 245, 721729.

9 K. Mahmoodi and B. Alinejad, Int. J. Hydrogen Energy, 2010, 35, 5227-5232.

10 S. S. Razavi-Tousi and J. A. Szpunar, Electrochim. Acta, 2014, 127, 95-105.

11 L. Soler, J. Macanás, M. Muñoz and J. Casado, J. Power Sources, 2007, 169, 144-149.

12 E. Czech and T. Troczynski, Int. J. Hydrogen Energy, 2010, 35, 1029-1037.

13 F. Franzoni, M. Milani, L. Montorsi and V. Golovitchev, Int. J. Hydrogen Energy, 2010, 35, 1548-1559.

14 H. W. Wang, H. W. Chung, H. T. Teng and G. Cao, Int. J. Hydrogen Energy, 2011, 36, 15136-15144.

15 Z. Y. Deng, Y. B. Tang, L. L. Zhu, Y. Sakka and J. Ye, Int. J. Hydrogen Energy, 2010, 35, 9561-9568.

16 Z. Y. Deng, J. M. F. Ferreira and Y. Sakka, J. Am. Ceram. Soc., 2008, 91, 3825-3834.

17 W. Z. Gai and Z. Y. Deng, Int. J. Hydrogen Energy, 2014, 39, 13491-13497.

18 L. Soler, A. M. Candela, J. Macanás, M. Muñoz and J. Casado, J. Power Sources, 2009, 192, 21-26.

19 W. K. Chen, J. L. Lee, C. Y. Bai, K. H. Hou and M. D. Ger, J. Taiwan Inst. Chem. Eng., 2012, 43, 989-995.

20 J. T. Qi, T. Hashimoto, J. R. Walton, X. Zhou, P. Skeldon and G. E. Thompson, Surf. Coat. Technol., 2015, 280, 317-329.

21 H. C. Yu, B. Z. Chen, X. Shi, X. Sun and B. Li, Mater. Lett., 2008, 62, 2828-2831.

22 H. Yu, B. Chen, H. Wu, X. Sun and B. Li, Electrochim. Acta, 2008, 54, 720-726.

23 N. T. Wen, C. S. Lin, C. Y. Bai and M. D. Ger, Surf. Coat. Technol., 2008, 203, 317-323.
24 K. W. Cho, V. S. Rao and H. S. Kwon, Electrochim. Acta, 2007, 52, 4449-4456.

25 F. Pearlstein and V. S. Agarwala, Plat. Surf. Finish., 1994, 81, 50-55.

26 F. Pearlstein and V. S. Agarawala, US Pat., US005304257A, 1994.

27 Y. Guo and G. S. Frankel, Surf. Coat. Technol., 2012, 206, 3895-3902.

28 Y. T. Chang, N. T. Wen, W. K. Chen, M. D. Ger, G. T. Pan and C. K. Yang, Corros. Sci., 2008, 50, 3494-3499.

29 X. Hu, X. Mao, X. Zhang and Y. Huang, Sens. Actuators, B, 2017, 247, 312-318.

30 J. Ding, Y. Liu, J. Zhang, M. Dong, Y. Wang, W. He, Z. Lang, K. Liu and J. Chen, Catal. Commun., 2017, 89, 106-110.

31 J. O. Nilsson, S. E. Hörnström, E. Hedlund, H. Klang and K. Uvdal, Surf. Interface Anal., 2004, 19, 379-385.

32 X. Zhang, W. G. Sloof, A. Hovestad, E. P. M. van Westing, H. Terryn and J. H. W. de Wit, Surf. Coat. Technol., 2005, 197, 168-176.

33 C. D. Wagner, W. M. Riggs, L. E. Davis, J. F. Moulder and G. E. Muilenberg, Handbook of X-Ray Photoelectron Spectroscopy, Perkin-Elmer Corp, Minnesota, 1978.

34 B. C. Bunker, G. C. Nelson, K. R. Zavadil, J. C. Barbour, F. D. W. And, J. P. Sullivan, C. F. Windisch, M. H. E. And and D. R. Baer, J. Phys. Chem. B, 2002, 106(18), 4705-4713.

35 H. X. You, X. U. Hong-Bin, Y. Zhang, S. L. Zheng and Y. Y. Gao, Chin. J. of Nonferrous Met., 2010, 20, s26-s31.

36 C. E. Barrera, J. Hazard. Mater., 2012, 223-224, 1-12.

37 K. Csobán and P. Joó, Colloids Surf., A, 1999, 151, 97-112.

38 W. Z. Gai, C. S. Fang and Z. Y. Deng, Int. J. Energy Res., 2014, 38, 918-925.

39 L. Soler, A. M. Candela, J. Macanás, M. Muñoz and J. Casado, Int. J. Hydrogen Energy, 2010, 35, 1038-1048.

40 O. Levenspiel, Chemical Reaction Engineering, Wiley, New York, 1999. 